NBER WORKING PAPER SERIES

\title{
STICKING IT OUT: ENTREPRENEURIAL SURVIVAL AND LIQUIDITY CONSTRAINTS
}

\author{
Douglas Holtz-Eakin \\ David Joulfaian \\ Harvey S. Rosen
}

Working Paper No. 4494

\author{
NATIONAL BUREAU OF ECONOMIC RESEARCH \\ 1050 Massachusetts Avenue \\ Cambridge, MA 02138 \\ October, 1993
}

We are grateful to Karin D'Agostino, Esther Gray and Kathleen Staudt for their assistance in preparing the manuscript, and to Bharat Anand, David Blanchflower, Bruce Meyer, Andrew Oswald, James Powell, Sherwin Rosen, Kenneth Small and an anonymous referee for useful suggestions. Financial support for this research was provided by the Center for Economic Policy Studies at Princeton University. The views in this paper do not represent the views of any of the institutions with which the authors are affiliated or the National Bureau of Economic Research. This paper is part of NBER's research program in Public Economics. 


\title{
STICKING IT OUT: ENTREPRENEURIAL SURVIVAL AND LIQUIDITY CONSTRAINTS
}

\begin{abstract}
We examine why some individuals survive as entrepreneurs and others do not. In addition, we analyze the growth of entrepreneurial enterprises, conditional on surviving. Our focus is on the role of access to capital -- to what extent do liquidity constraints increase the likelihood of entrepreneurial failure?

The empirical strategy is based on the following logic: If entrepreneurs cannot borrow to attain their profit-maximizing levels of capital, then those entrepreneurs who have substantial personal financial resources will be more successful than those who do not. The data consist of the 1981 and 1985 federal individual income tax returns of a group of people who received inheritances. These data allow us to identify those individuals who were sole proprietors in 1981 , and to determine the extent to which the decision to remain a sole proprietor was influenced by the magnitude of the inheritance-induced increase in liquidity.

The results are consistent with the notion that liquidity constraints exert a noticeable influence on the viability of entrepreneurial enterprises. For example, a $\$ 150,000$ inheritance increases the probability that an individual will continue as a sole proprietor by 1.3 percentage points, and conditional on surviving, the receipts of the enterprise increase by almost 20 percent.
\end{abstract}

$\begin{array}{lll}\text { Douglas Holtz-Eakin } & \text { David Joulfaian } & \text { Harvey S. Rosen } \\ \text { Metropolitan Studies Program } & \text { U.S. Dept. of the Treasury } & \text { Department of Economics } \\ \text { Syracuse University } & \text { Main Treasury Building } & \text { Princeton University } \\ \text { 400 Maxwell Hall } & \text { 1500 Pennsylvania Avenue, NW } & \text { Princeton, NJ 08544 } \\ \begin{array}{l}\text { Syracuse, NY 13244-1090 } \\ \text { and NBER }\end{array} & \text { Washington, D.C. 20220 } & \text { and NBER }\end{array}$




\section{INTRODUCTION}

Entrepreneurs are central to many issues in both economic theory and public policy.

Accordingly, economists have done a great deal of empirical research on entry into entrepreneurship -- who becomes an entrepreneur and under what conditions? ${ }^{1}$ However, the net quantity of entrepreneurs is just as dependent on departures from entrepreneurship as on the flows into entrepreneurship, and the former has received much less attention. A key issue in this context is one that is central to virtually all discussions of entrepreneurship -- access to capital. Do some entrepreneurs face liquidity constraints which make it more likely that their enterprises will fail? Even if they survive, are these entrepreneurs hobbled because they are under-capitalized? The notion that lack of capital inhibits the growth of small firms has been around at least since Adam Smith. Smith used the example of a small grocery store to illustrate this proposition: The owner of such an enterprise

"..must be able to read, write, and account, and must be a tolerable judge too, of perhaps fifty or sixty different sorts of goods, their prices, qualities, and the markets where they are to be had cheapest. He must have all the knowledge, in short, that is necessary for a great merchant, which nothing hinders him from becoming but the want of sufficient capital. "2

To date, there is little evidence with respect to whether "want of sufficient capital" affects firm survival and growth. ${ }^{3}$ Much of the empirical discussion of firm survival has taken place in the context of "Gibrat's Law," which states that a firm's rate of growth is independent of its size. Evans [1987] and Audretsch [1991] recognize that endogenous exit decisions may bias conventional statistical estimates of the relationship between firm growth and firm size. The corrective statistical procedure requires estimating models of firm exit rates. These models, however, do not include any consideration of liquidity constraints. ${ }^{4}$ Bates [1990] allows the probability of exit to depend on the entrepreneur's demographic characteristics, and explicitly considers the possibility that access to capital markets may affect survival 
probabilities. ${ }^{5}$ Specifically, Bates attempts to estimate how the amount of debt and equity capital obtained by entrepreneurs affects the viability of their enterprises. Unfortunately, because of severe multicollinearity problems, he is unable to include these variables in a logit analysis of exit decisions. In any case, as Bates recognizes, such variables are likely to be endogenous. Thus, the relationship between liquidity constraints and the viability of entrepreneurial enterprises remains an open issue.

In this paper, we examine why some individuals survive as entrepreneurs, and others don't. In addition, we analyze the growth of entrepreneurial enterprises, conditional on surviving. Section 2 introduces our analytic framework, which explicitly recognizes that there are several different paths out of entrepreneurship -- becoming a wage earner, joining a partnership, or simply retiring from the labor force.

In Section 3 we discuss the data and econometric issues. The data consist of the 1981 and 1985 federal individual income tax returns of a group of people who received inheritances in 1982 and 1983, along with information about the size of their inheritances. Any individual who is a sole proprietor must file a "Schedule $C^{n}$ with his or her tax return. Hence, we can construct a sample of individuals who were sole proprietors in 1981 , identify those who ceased being sole proprietors between 1981 and 1985 , and determine the extent to which this decision was influenced by the size of the inheritance-induced increase in assets. For those who remained entrepreneurs, we can assess how the inheritance affected the success of the enterprise, ceteris paribus. A problem that faces virtually all researchers who analyze the impact of liquidity constraints on firm behavior is that the measure of liquidity may be endogenous to various decisions of the firm. (See Hall [1992].) A particular appeal of this data set is that, as noted by Blanchflower and Oswald [1990], the receipt of an inheritance is 
about as close to a "natural experiment" as one is likely to get in this area, which reduces potential endogeneity problems.

Section 4 presents the results. They are consistent with the notion that liquidity effects exert a noticeable influence on the viability of entrepreneurial enterprises. For example, a $\$ 150,000$ inheritance increases the probability that an individual will continue as a sole proprietor by 1.3 percentage points, and the receipts of any surviving enterprise increase by almost 20 percent. We conclude in Section 5 with a summary and suggestions for furure research.

\section{ANALYTIC FRAMEWORK}

\section{$2.1 \quad$ Income Opportunities}

We analyze the choice faced by an individual who is currently self-employed. A preliminary analysis of the data indicated that four options are relevant for such an individual: retirement, employment as a wage and salary worker, continuing as a solo entrepreneur, and participation in a partnership or $S$ corporation. ${ }^{6}$ Although the four activities are not all mutually exclusive, it is convenient to consider the income opportunities of each in isolation.

Retirement. If the individual's assets are $A_{i}$ and the net rate of return is $r$, then income as a retiree is $Y_{i}^{R}=r A_{i}$.

Wage-Eaming. Denoting the individual's earnings potential as a wage-earner by $w_{i}$, the individual's income as a wage-earner is $Y_{i}^{W}=w_{i}+r A_{i}$. The variable $w_{i}$ is uncertain; its value is revealed to the individual only after he makes a decision to become a wage-earner.

Entrepreneurial Activities.' As an entrepreneur, an individual's gross receipts are $\theta_{i} f\left(k_{i}\right) \epsilon$, where $f(\cdot)$ is a production function whose only input is capital $\left(k_{i}\right), \theta_{i}$ is the 
individual's ability as an entrepreneur, and $\epsilon$ is a random component to the production process. Individuals know their ability $\left(\theta_{i}\right)$, but ability varies across individuals and is not observed by the analyst. We assume that $\epsilon$ has mean one and finite variance, and that $f(0)>0$-- the firm can produce output even in the absence of capital input. ${ }^{8}$ Recalling that $A_{i}$ is personal assets, $A_{i}-k_{i}$ is available to earn capital income, and the individual's net income as an entrepreneur is $Y_{i}^{\varepsilon}=\theta_{i} f\left(k_{i}\right) \epsilon+r\left(A_{i}-k_{i}\right)$. By definition, $k_{i}-A_{i}$ is the amount of capital financed by borrowing. We assume that the amount of borrowing, and thus capital invested in the enterprise, is bounded by a liquidity constraint generated by the financial markets. The size of the constraint depends on the individual's net assets: $k_{i} \leq l_{k}\left(A_{i}\right)$, where $l_{k}^{\prime}\left(A_{i}\right)>0.9$

An entrepreneur's optimal amount of capital, $k_{i}^{*}$, maximizes the expected value (where expectations are taken over $\epsilon$ ) of $Y_{i}^{E}$. This maximization problem has three possible solutions. In the first, the entrepreneur employs capital and the liquidity constraint is not binding. In this case, the net rate of return equals the expected marginal product of capital: $\theta_{i} f^{\prime}\left(k_{i}^{*}\right)=r$, and $k_{i}^{*}$ rises with the entrepreneur's ability. The second possibility is that the liquidity constraint is again not binding, but the entrepreneur's ability is sufficiently low that the marginal product of capital is below the interest rate. Hence, $k_{i}^{*}=0$. The final possibility is that the liquidity constraint is binding, so $k_{i}^{*}=l_{k}\left(A_{i}\right)$.

In what follows, we will need to trace the impact on the firm of changing $A_{i}$. The effect depends on whether the firm is liquidity constrained. If so,

$$
\frac{d k_{i}^{*}}{d A_{i}}=l_{k}^{\prime}\left(A_{i}\right)>0 .
$$

Otherwise, 


$$
\frac{d k_{i}^{*}}{d A_{i}}=0 .
$$

In general, then, $k_{i}^{*}$ is a function of $r, \theta_{i}$, and $A_{i}$, as istotal output of the firm. Thus, we can write the firm's revenues, $R_{i}$, as

$$
R_{i}=\theta_{i} f\left(k_{i}^{*}\right) \epsilon \equiv R\left(\theta_{i}, A_{i}, r, \epsilon\right) .
$$

Expression (2.3) embodies the prediction that an increase in the assets of a liquidity constrained entrepreneur increases the receipts of his enterprise, ceteris paribus -- higher assets lead to more capital, which generates greater output. Similarly, income as an entrepreneur is a function of these variables:

$$
Y_{i}^{\bar{E}}=\theta_{i} f\left(k_{i}^{*}\right) \epsilon+r\left(A_{i}-k_{i}^{*}\right) \equiv Y^{E}\left(\theta_{i}, A_{i}, r, \epsilon\right) .
$$

Because an increase in $A_{i}$ enables a liquidity-constrained entrepreneur to move closer to his optimal capital stock, economic profits or entrepreneurial income rises when he experiences an increase in assets.

Partnerships/S Corporations. To model the income opportunities associated with this option, one must address its fundamental nature. There are two possibilities. First, a partnership/S corporation may be a bona fide business venture that permits the entrepreneur to expand his enterprise. Alternatively, it may be a tax shelter that is essentially unrelated to the entrepreneur's original enterprise. As noted below, our data do not allow us to confront this issue on an observation-by-observation basis because we do not have information on either the entrepreneur's or the partnership's line of business. However, existing evidence suggests that by and large, the tax shelter view is more correct. Specifically, Statistics of Income data on partnerships for 1985 indicate that about 62 percent of partners were "limited partners, " i.e., investors who played essentially no role in the day-to-day activities of their enterprises. Hence, in developing our analysis, we focus on tax-shelter opportunities. ${ }^{10}$ 
The essence of tax-shelter investments is the ability to earn a net rate of return in excess of the net return on "regular" financial investments. However, these investments typically require a minimum level of investment before participation is possible. Denote the amount of tax-sheltered investment for an individual by $T_{i}$, the minimum investment level by $T_{m}$, and the net return by $\psi$. Hence, the individual's income is $Y_{i}^{s}=\psi T_{i}+r\left(A_{i}-T_{i}\right)$ where $T_{i}>T_{m}$. By their nature, tax shelters represent arbitrage opportunities, and as expressed here these opportunities are unbounded. In the spirit of our treatment of borrowing for an entrepreneurial enterprise, we assume that capital markets limit the ability to borrow for tax shelter investments: $T_{i} \leq l_{T}\left(A_{i}\right)$.

\section{$2.2 \quad$ Effects of Inheritance}

We now turn to the question of how an increase in personal assets -- especially an increase due to an inheritance -- affects the relative attractiveness of being an entrepreneur. An increase in assets affects the income associated with each option. It raises capital earnings in retirement or as a wage-earner, possibly increasing the desirability of these activities. Similarly, higher levels of personal assets make tax-shelter activity more attractive, either by enabling individuals to meet the minimum investment requirements, or by relaxing constraints on the amount invested.

Finally, by relaxing liquidity constraints, asset windfalls may raise the income associated with remaining an entrepreneur. However, for those entrepreneurs whose investment decisions are not liquidity-constrained, changes in personal assets do not affect the enterprises' receipts and profits. For these individuals, there are no incentives countering the increased attractiveness of the other three alternatives. Thus, some entrepreneurs may enter wage and 
salary employment or retire. Others may remain as entrepreneurs, but in addition make taxshelter investments.

Indeed, the minimum investment requirement for tax shelters may make it optimal for some to exit entrepreneurship entirely. Consider a "low- $\theta$ " entrepreneur. Such an individual has few assets invested in his enterprise, even if not liquidity-constrained. At the same time, he may not be able to meet the minimum investment requirements for tax-shelter activities whose return dominates that for his personal and entrepreneurial assets. An inheritance permits such an individual to liquidate his firm and move into tax shelters.

\subsection{Empirical Implementation}

We assume that the entrepreneur's choice among the four options is made along the lines suggested by Domencich and McFadden [1975]. The individual compares differences in the utilities of the various options and chooses the option with the highest utility. In order to make this framework operational, the first step is to postulate a distribution for the stochastic components of utility. We assume that these follow an extreme value distribution. The differences across options then follow a logistic distribution function. Under the conditions specified by Domencich and McFadden, this leads to the multinomial logit model as the appropriate framework for estimating how inheritance (and other variables) affect the incomeearning choices made by current entrepreneurs.

The second step is to specify a set of explanatory variables for the multinomial logit. The entrepreneur's decision depends on $A_{i}$ (because assets affect the income of each option), and the personal attributes that affect the shape of his or her utility function. That is, the decision depends upon relative ability in each mode, resources, and tastes. Our data allow us 
to include the following personal attributes; the value of each is taken before any transition is made:

Age. An individual's age may be correlated with his attitudes toward risk and toward the various nonpecuniary aspects of being an entrepreneur. In addition, age is related to the individual's years of labor market experience, and hence his or her human capital. To allow for nonlinearities, we include a quadratic term in age. In order to avoid confounding the effects of inheritance with those that occur when the individual reaches normal retirement age, we exclude from our sample entrepreneurs whose ages exceeded 58 years in 1981 .

Marital status and number of children. These two demographic variables may affect tastes for the various modes, although the direction of their effect is not clear. Having to support a family, for example, might make a person less likely to continue in relatively risky ventures. At the same time, however, the presence of family support might make it easier to keep a business going.

Adjusted Gross Income (AGI). AGI is the most comprehensive measure we have of household income. It includes the earnings of both spouses as well as capital income. It controls for any income effects that may be involved in the choice among modes.

Employment status of donor. Lentz and Laband [1990] and others have argued that children of entrepreneurs acquire informal business experience from their parents. In terms of our theory, children of entrepreneurs may be "high- $\theta$ " people. Of course, tax returns do not ask about parents' lifetime occupations. However, we were able to obtain the 1981 personal income tax returns of the donors and determine whether they included a Schedule C. We include a dichotomous variable indicating whether or not the donor filed a Schedule C. Assuming that this effect depends on the closeness of the relationship between the donor and 
the beneficiary, we also include a variable that interacts the donor's Schedule $C$ variable with an indicator for whether the recipient is a son or a daughter. A reasonable question is whether these variables are in some sense reflecting the budget constraint -- children of entrepreneurs may be more likely to inherit physical assets that may be of direct use in their own businesses. However, as noted below, we have a separate variable that indicates whether the estate included a business.

Another indicator of the individual's ability to function as an entrepreneur is the actual performance of his enterprise prior to the time that the inheritance is received. How do we measure the firm's "performance?" According to our model, one relevant measure of the flrm's performance is its gross receipts (see equation (2.3)). This variable is included in our data. A second possible indicator is the firm's economic profits. We have no information on the amount of capital invested in the enterprise, so we cannot compute economic profits. Instead, we use an admittedly imperfect alternative, reported net income or loss plus depreciation allowances, which we call "cash flow." ${ }^{11}$ In our empirical work, we estimate all of the models twice, once with receipts and once with cash flow, to see if the substantive results are robust with respect to the choice of performance measure.

Importantly, we expect the enterprise's prior performance to be a function of variables that are not available in our data. Examples are the entrepreneur's education, race, and gender. In addition, performance depends on characteristics of the business, such as age of the enterprise, line of business, and prior investments in reputation and physical capital. Previous analyses have argued that these variables are important determinants of the decision to enter or leave entrepreneurship. ${ }^{12}$ By including prior performance in the multinomial logit, we are at least partially taking these variables "into account." 
We turn next to the measurement of $A_{i}$, the individual's assets. ${ }^{13}$ Our data provide different amounts of information on various assets. Dividends and interest are reported on tax returns; with suitable assumptions on capitalization rates, we can impute the stock of assets that generated these flows and include it in the model ${ }^{14}$ Preliminary analysis of the data indicated that the stock of liquid assets has a nonlinear effect on our dependent variables; hence, a quadratic term is also included. We are unable to make any meaningful imputations on the value of owner-occupied housing, but on the basis of information on mortgage interest and property tax deductions, we can create a dichotomous variable indicating whether or not the family owns a home.

The centerpiece of our analysis is the entrepreneur's inheritance. As noted above, we wish to view the coefficient on the inheritance as telling us something about the presence or absence of liquidity constraints. In this regard, several issues arise. First, if bequests include businesses, then there may be a positive correlation between surviving as an entrepreneur and the size of an inheritance that has nothing to do with liquidity constraints. To allow for this possibility, we include a dichotomous variable (DBUS) that is equal to one if the estate included a business. Another possibility is that the inheritance proxies for the transfer of business skills. However, as noted above, we include a variable to capture transfers of entrepreneurial skills from donors. In addition, one expects that superior entrepreneurial human capital would manifest itself in above-average performance of the firm, and our model includes a measure of the firm's prior performance.

Finally, certain bequest motives might generate a spurious correlation between inheritance and entrepreneurial survival. For example, individuals might choose to leave particularly large inheritances to their relatives who are working very hard at developing new 
businesses. Such behavior could generate a positive relationship between the size of an individual's inheritance and his business success that has nothing to do with liquidity constraints. ${ }^{\text {Is }}$ In his examination of the U.S. Treasury estate tax flles from which our data are drawn, Wilhelm [1993] found that roughly two-thirds of the estates provided equal division among the beneficiaries. In the remaining one-third of the estates, the division was not equal, but it was uncorrelated with income, ceteris paribus. While the controversies surrounding bequest motives remain far from settled, there appears to be no evidence in our data that inheritances are endogenous with respect to skill as an entrepreneur.

\section{DATA AND ECONOMETRIC ISSUES}

\section{$3.1 \quad$ Data}

As noted earlier, our empirical analysis is based on tax return data. One issue that arises when using such data relates to a problem faced by every empirical researcher in this area -- making operational the notion of entrepreneurship. How do we know who is an entrepreneur? In the nonstatistical literature on this topic, entrepreneurs are characterized in terms of their daring, risk-taking, animal spirits, and so on:

"To act with confidence beyond the range of familiar beacons and to overcome that [social] resistance requires aptitudes that are present in only a small fraction of the population and that define the entrepreneurial type..."

(Schumpeter [1942], p. 132)

Those who do statistical work must settle for observable (and hence, more prosaic) criteria for classifying someone as an entrepreneur. With tax return data, the most sensible proxy for "entrepreneurship" is the presence of a Schedule C in the tax return.

One could argue that the presence of Schedule $C$ is not really indicative of entrepreneurial activity. For example, some academic economists report their consulting 
income and honoraria on Schedule $\mathrm{C}$, but do not consider themselves entrepreneurs. However, data from the 1985 Statistics of Income indicate that such personal service activities are undertaken by only a small proportion of Schedule C filers, about 16 percent. ${ }^{16}$ And surely at least some of these activities reflect Schumpeterian entrepreneurial behavior. ${ }^{17}$

Other users of tax-based data have employed broader criteria for classifying people as entrepreneurs. For example, the Characteristics of Business Owners data characterize as "entrepreneurs" members of partnerships and S corporations as well as sole proprietors. However, as described earlier, we believe that in many cases partnerships and $\mathrm{S}$ corporations may be more reflective of tax shelter activity than entrepreneurship. A practical advantage of a Schedule $\mathrm{C}$ criterion is that this schedule includes some specific information on the activities of the enterprise. In contrast, individual tax return data do not provide such information about partnerships and $\mathrm{S}$ corporations. ${ }^{18}$ Nevertheless, to assess the robustness of our results, we report below the result of classifying members of partnerships and $S$ corporations as entrepreneurs.

Of course, an individual can file a Schedule $\mathrm{C}$ while also being involved in a partnership. For that matter, he can simultaneously be employed as a wage and salary worker as well. It is infeasible to estimate models of transitions out of and into all of the possible combinations of the various states. Therefore, the empirical model maintains the four-way classification embodied in our theoretical model, adopting the following algorithm for allocating individuals to the various modes. If an individual files a Schedule $\mathrm{C}$, he is classified as an "entrepreneur," regardless of any other information included on the return. If an individual has partnership/S corporation income but no Schedule $\mathrm{C}$, he is categorized as being in a "partnership/S corporation." If an individual has wage income but no Schedule $\mathrm{C}$ and no 
partnership/S corporation, he is categorized as a "wage-earner." Finally, if he has none of the above, he is "retired. ${ }^{\text {19 }}$

A final issue concerns the representativeness of the data set. The sample consists only of individuals who received inheritances from substantial estates. Such individuals tend to have very high pre-inheritance incomes. The mean 1981 AGI per return in our sample is $\$ 31,700$, about $\$ 12,000$ above the mean for all tax filers. The AGIs on returns with a Schedule $\mathrm{C}$ are even higher, with a mean value of over $\$ 67,000$. (See Table 3.1.) Clearly, such individuals are not typical, and we make no claims that our results apply to the population as a whole. However, the results do allow us, in effect, to bound the importance of liquidity constraints. If anyone has good access to capital markets, it should be such high income individuals. To the extent that their decision-making is affected by liquidity constraints, it is likely that capital market constraints will be at least as important for lower income individuals.

Construction of our data set began with an Internal Revenue Service (IRS) sample of estate tax records. The IRS selected a one percent random sample of estate tax returns of people who died in 1982 and whose estate tax returns were filed in 1982 and 1983 . Returns with total assets over one million dollars were selected at a 100 percent rate. The sample included over 8,500 individuals with gross estates over $\$ 300,000$.

The next step was to match the estate tax returns with the decedents' personal income tax rerurns for 1980 through 1982, and with the beneficiaries' personal income tax returns for 1980 through 1982 and 1985 . We dropped some observations because of the inability to make matches, missing data, etc. The number of observations with usable information for these two years was 7,036. As noted above, our focus is on the survival probabilities of individuals who were entrepreneurs in 1981. In our data, 1,892 individuals were sole proprietors in 1981; these 
observations comprise our basic sample. The means and standard deviations of the variables for this sample are reported in Table 3.1 .

The mean inheritance in the sample is $\$ 178,250$. The range of this variable is wide; some donees received bequests of as little as $\$ 100$, while the maximum exceeded $\$ 3$ million. The members of this group are quite wealthy -- the mean value of liquid assets is over $\$ 325,000$. We should note, however, that this figure is an estimate arrived at by capitalizing interest receipts using a rate of return of 10 percent, and dividends using a rate of return of 5 percent. (See Skinner and Feenberg [1990].) Clearly, such a measure of liquid assets is only a rough approximation to the true value. In contrast, the inheritance variable is based on administrative records and is quite accurately measured. Hence, it is this variable to which we pay most attention when trying to gauge the impact of personal wealth on various decisions.

The focus of our analysis is on what entrepreneurs do after they receive their inheritances. The matrix in Figure 3.2 contains information on the transitions made by members of our sample by size of inheritance. The columns of the matrix show the possible modes in 1985: remaining in Schedule $\mathrm{C}$, being in a partnership/S corporation and not having a Schedule $\mathrm{C}$, earning wages and not having any business income, and retiring. The rows group the individuals into "low" (under $\$ 25,000$ ), "medium" (between $\$ 25,000$ and $\$ 150,000$ ) and "high" (greater than $\$ 150,000$ ) inheritance classes. The fourth row and fifth column provide corresponding summary information. The first figure in each cell is the number of individuals in that cell; the second number is the proportion of observations in the corresponding row that fall in that cell; and the third number is the standard deviation of the proportion. Thus, for example, the figures in the second row and first column tell us that of the entrepreneurs who 
received a mid-sized inheritance, 461 continued as entrepreneurs and this represents about 70 percent of the entrepreneurs who were in that inheritance class.

According to Table 3.2, a substantial proportion of the entrepreneurial enterprises do not survive -- only about 72 percent of the enterprises that were present in 1981 are alive in 1985. Moreover, the survival rate increases with inheritance, going from 67.4 percent in the low inheritance class to 76.5 percent in the high inheritance class, a difference that is statistically significant at the 1 percent level.$^{20}$ About 15 percent of the individuals who cease being entrepreneurs become involved in partnerships or $S$ corporations. However, there appears to be no obvious relationship between the propensity to enter a partnership/S corporation and the size of inheritance. The third column indicates that the proportion who leave entrepreneurship for wage earning declines with the inheritance; these declines are also statistically significant. The last column shows that the proportion of entrepreneurs who retire altogether rises with inheritance. More generally, a test of the null hypothesis that all the transitions are invariant with respect to inheritance levels is rejected at the l percent level. ${ }^{21}$

While the tendencies exhibited are generally consistent with out theoretical model, the theory suggests that a number of other variables in addition to inheritance may affect transition decisions. We next turn to a discussion of some econometric issues that arise in doing a multivariate analysis.

\subsection{Econometric Issues}

Our goal is to develop an econometric framework for analyzing the aspects of entrepreneurship highlighted by our theory: the likelihood of surviving as an entrepreneur, and the success of the enterprise, conditional on its surviving. 
The probability that an individual makes a transition out of entrepreneurship depends on the unobserved components of utility, as well as observed assets (including inheritance) and personal characteristics. For reasons discussed in Section 2, we also include a measure of the performance of the enterprise prior to receiving the inheritance. As noted above, we use a multinomial logit model. Turning now to the performance of the firm, equation (2.3) indicates that the firm's receipts $\left(R_{i}\right)$ depend on the levels of personal assets and unobserved entrepreneurial ability $\left(\theta_{i}\right)$. As in the modal choice equations, we also include the lagged value of performance as a partial control for "entrepreneurial ability."

The model in Section 2 suggests that the decision to remain an entrepreneur and the performance of the firm, conditional on surviving, are inextricably linked, as both $R_{i}$ and utility are driven in part by the variable $\theta_{i}$, unobservable (to the analyst) entrepreneurial ability. This joint role for $\theta_{i}$ means that the error terms in the relationships determining the probability of surviving and the performance (conditional on surviving) will likely be correlated. The situation differs somewhat from the usual selectivity bias problem discussed by Heckman [1976], because the error term in the first stage is not normally distributed. However, Lee [1983] provides a generalization of Heckman's two-stage procedure that can accommodate this situation. In the first stage, conventional multinomial logit estimation is used to estimate the transition probabilities. In the second stage, the performance equation is estimated by ordinary Ieast squares (augmented with the inverse Mills ratio, computed as indicated by Lee), with the required correction of the standard errors. 


\section{4. $\quad$ RESULTS}

\subsection{Basic Results}

As indicated earlier, we expect that the probability of exiting will depend on the previous performance of the enterprise, inter alia, and we have two alternative measures, receipts and cash flow. Because the two measures give substantially the same qualitative results, we focus in this section on the receipts measure; the estimates with cash flow are included in the Appendix (Table A.1 and equation (A.1))

To begin, we report in Table 4.1 the multinomial logit results for entrepreneurial survival rates. The first column shows the determinants of the odds of surviving as an entrepreneur relative to becoming a wage-earner. From a statistical point of view, the most significant of the demographic variables is age. ${ }^{22}$ The negative quadratic term begins to dominate the positive linear term at roughly the age of 44 , indicating that past this age, people become more likely to opt out of entrepreneurship in favor of wage-earning, ceteris paribus. This might be due to an increased desire for security as age increases, but other forces could also be at work.

With respect to liquidity constraints, the key variables are inheritance and liquid assets. The inheritance variable has a positive coefficient that exceeds its standard error by about a factor of three. Thus, receiving an inheritance increases the probability that an entrepreneur will stay in business rather than become a wage earner. Similarly, the coefficient on the level of liquid assets is positive and statistically significant. (Although the negative quadratic term in assets is statistically significant, it does not dominate the linear term until it is outside the range of our data.) These findings are consistent with the presence of liquidity constraints. Finally, we note that, unsurprisingly, the more successful the enterprise was prior to receiving an 
inheritance, the more likely the entrepreneur is to continue in business rather than become a wage eamer -- the coefficient on RECPT81, the level of receipts in 1981 (measured in 1985 dollars), is positive and exceeds its standard error by about a factor of three.

Column (2) has the results for the probability of joining a partnership or S corporation relative to becoming a wage earner. To make comparisons to the probability of sticking it out as an entrepreneur, we must compare the coefficient in column (2) to the corresponding coefficient in column (1), ${ }^{23}$ Doing so indicates that the receipt of an inheritance makes it less likely that an individual will move to a partnership/S corporation.

The positive coefficient on RECPT81 in column (2) must be interpreted in a similar fashion. Even if the coefficient were statistically significant, it would not imply that an increase in prior performance increases the attractiveness of a tax shelter relative to remaining an entrepreneur, because the point estimate (1.983) is less than the corresponding coefficient in the first column (4.319). As common sense suggests, better previous performance increases the probability of sticking it out relative to joining a partnership.

The last column of Table 4.1 examines the probability of retiring relative to entering wage earning. Consistent with earlier work on the relationship between inheritance and labor force behavior, inheritances are an inducement to retire. ${ }^{24}$ Indeed, if we compare the coefficient on INH to its counterparts in columns (1) and (2), we see that an increase in inheritance increases the odds of retirement relative both to joining a partnership, and remaining an entrepreneur. The age variables in column (3), although individually insignificant, are jointly significant. (A Wald test produces a chi-squared statistic of 13.79; with two degrees of freedom, the critical value at a 0.99 significance level is 9.21 .) The 
positive quadratic term dominates throughout essentially the entire relevant range of ages -- the probability of retirement increases with age, an intuitive finding.

So far, our focus has been on the qualitative effects of inheritance on transition probabilities. To investigate the quantitative impact, we used the estimated coefficients in Table 4.1 to compute at the sample means the predicted probabilities of remaining as an entrepreneur (0.776), moving to a partnership/S-corporation $(0.147)$, becoming a wage-earner (0.0737), or retiring $(0.00290)$. We then increased inheritance by $\$ 150,000$ (in 1985 dollars), and re-computed the probabilities. The result is that the probability of surviving as an entrepreneur rises by 0.013 , which is virtually offset by a 0.014 decline in the probability of becoming a wage-earner. The impact on the remaining probabilities, while positive, is minuscule

However, our theory suggests that the possible influence of liquidity constraints may extend beyond the survival probability. As implied by expressions (2.1) and (2.2), liquidity constraints may be present if firm performance depends on any of the asset variables. ${ }^{25}$ We therefore used the sample of individuals who remained as entrepreneurs to see if the asset variables affect receipts in 1985 (RECPT85):

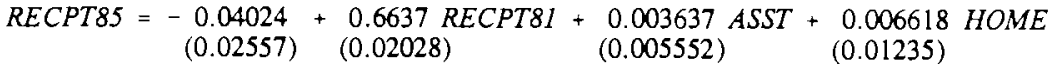

$$
\begin{aligned}
& +0.004769 \text { DBUS + } 0.1002 I N H+0.08429 \lambda \\
& \begin{array}{lll}
(0.009951) \quad(0.01735) \quad(0.03953)
\end{array}
\end{aligned}
$$

where $\lambda$ is the inverse Mills ratio. ${ }^{26}$ The results with respect to inheritance are quite striking. ${ }^{27}$ The coefficient exceeds its standard error by almost a factor of six. To assess the quantitative implications of the estimate, note that the mean value of RECPT85 is $\$ 79,129$. An inheritance of $\$ 150,000$ would increase this to about $\$ 94,160$, an increase of nearly 20 percent. 
Even this computation may understate the full effect. The results of Holtz-Eakin, Joulfaian, and Rosen [1993] suggest that receipt of an inheritance reduces labor supply, conditional upon not retiring. If so, holding labor supply constant would yield an ever greater increase in receipts. In short, by relaxing capital market constraints, inheritances have a substantial impact on the success of on-going concerns.

\subsection{Alternative Specifications}

To the extent that people respond differently to anticipated and unanticipated inheritances, our failure to distinguish between these is a source of specification error. Of course, we have no direct way to decompose an inheritance into its anticipated and unanticipated components. However, it is possible that children of a decedent are more likely to anticipate their inheritances than other relations. Hence, comparing the transition probabilities of children of decedents with other recipients might shed some light on this issue. We therefore defined a dichotomous variable that equalled one if the donee was a child of the donor and zero otherwise, multiplied it by $I N H$, and augmented the multinomial logit equation with this interaction term.

The interaction term was insignificant -- a likelihood ratio test produced a statistic of 5.8 , while the critical value of a chi-square distribution with 3 degrees of freedom at the 95 percent level is 7.81. Taken at face value, this suggests no difference between anticipated and unanticipated inheritances. However, one must take this observation with a grain of salt, since the interaction variable may not adequately reflect the extent to which an inheritance is anticipated. 
Another possible source of specification error arises from the fact that liquidity constraints may not be very important for people who have high income or wealth. Perhaps it is inappropriate to assume that high- and low-asset people respond in the same way to receipt of an inheritance. Therefore, despite the problems in measuring liquid assets discussed above, it seemed worthwhile to permit the coefficients on inheritances for people with liquid assets greater than some cutoff level to differ from those with less than that amount. Choosing $\$ 65,000$ (the approximate median) as the break point, we found that the point estimates for the high-asset group are slightly larger, but one cannot reject the null hypothesis that the coefficients are the same. For example, in the multinomial logit equation, the chi-square test is 2.6 with 3 degrees of freedom. Thus, at least within the range of liquid asset values present in our data, the effect of inheritance is independent of the size of liquid assets.

An additional potential problem relates to the criteria for classifying an individual as an entrepreneur. As noted above, we have treated partnerships and $S$ corporations as tax shelters rather than entrepreneurial enterprises. Do our substantive results change if they are accorded the same status as sole proprietorships? To answer this question, we pooled all the 1981 returns that had income from a sole proprietorship or a partnership or an $\mathrm{S}$ corporation. This gave us a sample of 3,520 observations, which we deemed to be the group of initial entrepreneurs. We then estimated multinomial logit equations for transition probabilities into three states: remain an entrepreneur (Schedule C, partnership, or S corporation), wage and salary earner, and retirement. The full set of results is reported in the Appendix (Table A.2). For our purposes, the key finding is that inheritance continues to exert a positive and statistically significant impact on surviving as an entrepreneur relative to becoming a wageearner. (The coefficient on $I N H$ is 1.641 with a standard error of 0.409 .) Hence, while we 
prefer the Schedule $C$ criterion for entrepreneurship, a more inclusive criterion does not lead to very different results.

A related concern is that, as noted above, the mere filing of a Schedule $\mathrm{C}$ may not be indicative of "serious" entrepreneurial activity. We therefore reestimated the basic model using the criterion that an individual file a Schedule $\mathrm{C}$ and have a cash flow that exceeds $\$ 5,000$. The results with respect to inheritance are quite similar to those in Table 4.1. The coefficient on INH in the "survive as entrepreneur" branch is 1.610 (s.e. $=0.770)$; in the "partnership/S corporation" branch 1.723 (s.e. $=0.812$ ); and in the "retire" branch 2.448 (s.e. $=0.928$ ). (The complete set of results is available upon request.) Hence, a more stringent definition of an entrepreneur does not affect the basic story.

In summary, the substantive results reported in Table 4.1 do not appear to be sensitive to the distinction between anticipated and unanticipated inheritances, to interactions between the level of liquid assets and inheritance, and to reasonable changes in the criteria for classifying an individual as an entrepreneur.

\section{SUMMARY}

Are U.S. entrepreneurs undercapitalized? Our investigation of this question has been based on the following logic: if entrepreneurs cannot borrow to attain their profit-maximizing levels of capital, then those entrepreneurs who have substantial personal financial resources are more successful than those who do not. Their enterprises are more likely to survive, and conditional on surviving, they perform better. In order to execute this research strategy convincingly, one needs a source of asset variation that is both precisely measured and exogenous to the entrepreneur's decisions. Our data are uniquely well-suited for this purpose. 
The sample consists of the 1981 and 1985 federal tax returns of a group of people who received inheritances in 1982 and 1983, along with information on the size of those inheritances from a matched set of bequest tax returns. Hence, we can examine how the exogenous receipt of capital affects the probability of entrepreneurial survival and the performance of the enterprise.

Straightforward tabulations of the data indicate that after receiving their inheritances, our entrepreneurs do a variety of things -- some remain entrepreneurs, some enter tax shelters, some take employment as wage earners, and a few simply retire. Hence, our theoretical and empirical models encompass all these options. The results suggest that the effect of inheritance on the probability of surviving as an entrepreneur is small but noticeable -- a $\$ 150,000$ inheritance raises the probability of survival by about 1.3 percentage points. Conditional on surviving, inheritances have a substantial impact on entrepreneurial enterprises -- the $\$ 150,000$ inheritance, for example, is associated with a nearly 20 percent increase in an enterprise's receipts. ${ }^{28}$

Our finding that sole proprietorships are undercapitalized is consistent with the results of Fazzari, Hubbard, and Petersen [1988], Hall [1992], and others, which suggest that even corporations are constrained in capital markets. Thus, there is growing evidence that capital market imperfections exert an important influence on business and capital formation. 


\section{Appendix}

\section{Alternative Specifrcations}

This Appendix presents the results when we depart from the specification in Table 4.1. Table A.1 shows the outcome when the multinomial logit equations in Table 4.1 are reestimated, using cash flow in 1981 to replace receipts as the measure of the firm's prior performance. A comparison of Tables 4.1 and A.1 suggests that the results are virtually unchanged. The second stage equation for this specification is:

$$
\begin{aligned}
& \text { CASH85 }=-0.04169+0.8811 \text { CASH8I }+0.006272 \text { ASST }+0.006776 \text { HOME } \\
& (0.008667)(0.02122) \quad(0.001890) \quad(0.004081) \\
& +0.003076 \mathrm{DBUS}+0.01542 \mathrm{INH}+0.07725 \lambda \text {, } \\
& (0.003278) \quad(0.005853) \quad(0.01339)
\end{aligned}
$$

where CASH85 and CASH8I are cash flow in 1985 and 1981 (measured in 1985 dollars), respectively, and the other variables are as defined in the body of the paper. Just as was the case when receipts were used as the measure of firm performance (equation (4.1)), inheritance and liquid assets are both statistically significant. Substituting into equation (A.1), the coefficient on $I N H$ implies that a $\$ 150,000$ inheritance would increase $C A S H 85$ by $\$ 2,313$. The mean value of CASH85 is $\$ 22,492$; hence, this represents a 10 percent increase.

We next turn to the results when the definition of entrepreneurship is expanded to include participants in partnerships and $\mathrm{S}$ corporations, as well as sole proprietors.

Mechanically, this involves combining the sole proprietors and participants in partnerships and $S$ corporations into a single category in 1981 . In 1985 , they may remain in this category, become wage earners, or retire. The multinomial logit estimates are presented in Table A.2.29 As in Table 4.1, the probability of remaining an entrepreneur (relative to becoming a wage earner) increases with inheritance. 


\section{$\underline{\text { Endnotes }}$}

1. See, for example, Evans and Leighton [1989], Evans and Jovanovic [1989], and HoltzEakin, Joulfaian, and Rosen [1992]. Meyer [1990] surveys much of this literature.

2. Quoted in Shorrocks [1988, p. 256].

3. Brock and Evans [1986, Chapter 3] survey the theory of firm exit decisions.

4. Other empirical studies include Baldwin and Gorecki [1991] and Schary [1991].

Schary's analysis of the cotton textile industry uses working capital per spindle as a measure of liquidity. She finds that it has no statistical effect on survival probability. However, this variable is likely to be endogenous. See Hall [1992].

5. Meyer [1990] also examines individuals' transitions out of self-employment, but his analysis is confined to the first eight months of the life of the enterprise.

6. An $\mathrm{S}$ corporation is a corporation whose income is treated like that of a partnership -the income is taxed at the individual level and escapes the corporate "double tax." An $S$ corporation may have no more than 35 stockholders.

7. This discussion of the income potential of an entrepreneur is based on Evans and Jovanovic [1989] and Holtz-Eakin, Joulfaian, and Rosen [1992].

8. This assumption conforms with the empirical fact that roughly 60 percent of new entrepreneurs have no depreciable capital. See Meyer [1990].

9. We do not pursue here the source of these constraints. A number of papers have shown how liquidity constraints can emerge even in a model where all individuals optimize. See, for example, Stiglitz and Weiss [1981].

10. Nevertheless, the possibility remains that such enterprises should be treated symmetrically with sole proprietorships. In the empirical work presented below, we estimate a variant of the basic model that does so.

11. Our treatment of depreciation allowances is dictated by the Economic Recovery Tax Act of 1981, which made depreciation schedules more generous in 1985 than they were in 1981. This change makes it problematic to compare incomes net of depreciation across the two years.

12. See Meyer [1990] on the role of race, Bates [1990] on education, and Evans [1989] on age of enterprise. Unfortunately, the "principal business code" from Schedule $C$ was not included in our data, so we were unable to categorize the firms by line of business.

13. We restrict attention to the assets of the individual as tax-return data provide no measure of the assets of the firm. 
14. We have no data on tax-exempt assets.

15. An alternative mechanism, along the lines suggested by Cox [1987], is one in which higher skill and thus higher income individuals ieceive larger inheritances in order to induce them to provide services to their benefactors.

16. This figure includes "business services" (advertising, management consulting, public relations, computer services, etc.) and "accounting and bookkeeping services".

17. A possible problem is that the mere filing of a Schedule $\mathrm{C}$ may not be indicative of "serious" entrepreneurial activity. We therefore also estimate the model using the criterion that the Schedule $C$ reported a cash flow of at least $\$ 5,000$.

18. Specific information on a partnership is recorded on Form 1065, Partnership Income Tax Return. Our data are from Form 1040 (Individual Income Tax Return), which contains only the net income or loss allocated to the partner filing the return.

19. Of the 1,892 returns that included a Schedule $C$ in 1981, 220 also reported partnership/S corporation income; 840 also reported wage income; and 498 also reported both partnership/S corporation and wage income. Of course, the need to make some fairly arbitrary classifications is not unique to these data. For example, in the Survey of Income and Program Participation, a number of individuals report income from both wage and self-employment. Typically, classification is made on the basis of the individual's income or hours of work in each mode; see Meyer [1990]. However, we have no measure of income that meaningfully reflects the intensity of involvement in each mode.

20. One might like to augment this analysis with information on the behavior of a control group receiving no inheritances. Unfortunately, income tax data do not identify recipients of inheritances, so it is not possible to construct such a sample. To allow at least a rough comparison we use a random sample of nearly 6.5 million schedule $C$ filers drawn from 1981 tax returns. In this sample, 66.2 percent survived as entrepreneurs until 1985, 3.2 percent made a transition to a partnership/S corporation, 29.1 percent became wage and salary earners, and 1.53 percent retired. Hence, as we move from the low-inheritance group to the "no inheritance" control group, the tendencies in Figure 3.2 persist. For example, the fraction of entrepreneurs who survive is greater for the low inheritance group than for the random sample.

21. The chi-square test statistic is 36.5 with six degrees of freedom.

22. Note that the family background variables, $D C$ and $D C \times C H I L D$, are not statistically significant. Bates [1990] found that a similar variable, which indicated whether any close family members had been self-employed, did not affect survival probabilities.

23. This is because, in general, the log of the odds of remaining an entrepreneur relative to 
moving into a partnership is $\sum_{j=1}^{N}\left(\beta_{j}^{\varepsilon}-\beta_{j}^{P}\right) Z_{i j}$, where the superscripts $E$ and $P$ denote entrepreneurship and partnership, respectively.

24. See Holtz-Eakin, Joulfaian, and Rosen [1993].

25. A possible source of concern is that liquid assets and receipts might be correlated simply because larger firms require greater working capital. However, we examine the relationship between receipts in 1985 and liquid assets in 1981 , a time span much longer than would be dictated by working capital considerations. Also, we control for the size of the business by including the lagged level of receipts. In any case, as noted above, our focus is on inheritance rather than liquid assets, because of the potential for endogeneity in the latter.

26. Recall from Section 3 that the variable $\lambda$ is computed according to the method suggested by Lee [1983]. The fact that its coefficient is positive is consistent with the view, embodied in our model, that the likelihood of survival and firm performance, conditional on survival, are both driven by the individual's unobservable ability as an entrepreneur.

27. In this equation, $I N H$ is measured in 1985 dollars rather than dollars in the year received (1983) in order to facilitate comparisons to receipts in 1985.

28. These results are reminiscent of those in Holtz-Eakin, Joulfaian and Rosen [1992], who find that inheritances have a relatively small direct impact on the decision to launch entrepreneurial ventures, but a larger influence on the capitalization of new firms.

29. Unlike Table 4.1, there is no measure of "previous performance" such as receipts, because we do not have this information for partnerships and $S$ corporations. 


\section{$\underline{\text { References }}$}

Audretsch, David, "New-Firm Survival and the Technological Regime," The Review of Economics and Statistics, 1991, pp. 441-450.

Baldwin, John R. and Paul K. Gorecki, "Firm Entry and Exit in the Canadian Manufacturing Sector, 1970-1982," Canadian Journal of Economics, May 1991, pp. 300-323.

Bates, Timothy, "Entrepreneur Human Capital Impacts and Small Business Longevity," The Review of Economics and Statistics, 1990, pp. 551-559.

Blanchflower, David, and Andrew Oswald, "What Makes an Entrepreneur?" London School of Economics, mimeo, 1990.

Brock, William A. and David S. Evans, The Economics of Small Business, New York: Holmes and Meier, 1986.

Cox, Donald, "Motives for Private Income Transfers," Journal of Political Economy, 95, June 1987, pp. 508-546.

Domencich, Thomas and Daniel McFadden, Urban Travel Demand, Amsterdam: North Holland Publishing Company, 1975.

Evans, David S., "Tests of Alternative Theories of Firm Growth," Journal of Political Economy, August, 1987, pp. 657-674.

Evans, David S. and Linda Leighton, "Some Empirical Aspects of Entrepreneurship," American Economic Review, 1989, pp. 519-535.

Evans, David S. and Boyan Jovanovic, "An Estimated Model of Entrepreneurial Choice Under Liquidity Constraints," Journal of Political Economy, 1989, pp. 808-827.

Fazzari, Steven, R. Glenn Hubbard and Bruce C. Petersen, "Financing Constraints and Corporate Investment," Brookings Papers on Economic Activity, No. 1, 1988, pp. 141-195.

Hall, Bronwyn H., "Investment at the Firm Level: Does the Source of Financing Matter?" National Bureau of Economic Research, Working Paper No. 4096, June 1992.

Heckman, James, "The Common Structure of Statistical Models of Truncation, Sample Selection, and Limited Dependent Variables and a Simple Estimator for Such Models," Annals of Economic and Social Measurement, 1976, pp. 475-492. 
Holtz-Eakin, Douglas, David Joulfaian, and Harvey S. Rosen, "Entrepreneurial Decisions and Liquidity Constraints," mimeo, Syracuse University, 1992.

Holtz-Eakin, Douglas, David Joulfaian, and Harvey $\mathbf{S}$. Rosen, "The Carnegie Conjecture: Some Empirical Evidence," Quarterly Journal of Economics, CVIII, No. 2, May 1993, pp. 413-436.

Lee, Lung-Fei, "Generalized Econometric Models with Selectivity," Econometrica, March 1983, pp. 507-512.

Lentz, Bernard S. and David N. Laband, "Entrepreneurial Success and Occupational Inheritance Among Proprietors," Canadian Journal of Economics, XXIII, August [990, pp. 563.579 .

Meyer, Bruce, "Why Are There So Few Black Entrepreneurs?" National Bureau of Economic Research, Working Paper No. 3537, 1990.

Schary, Martha, "The Probability of Exit," RAND Journal of Economics, Autumn 1991, pp. 339-353.

Schumpeter, Joseph, Capitalism, Socialism and Democracy, New York: Harper and Row Publications, 1942.

Shorrocks, Anthony, "Wealth Holdings and Entrepreneurial Activity" in Kessler, D. and A. Masson (eds.) Modeling the Accumulation and Distribution of Wealth, Oxford: Clarendon Press, 1988, pp. 241-258.

Skinner, Jonathan and Daniel Feenberg, "The Impact of the 1986 Tax Reform Act on Personal Saving," National Bureau of Economic Research, Working Paper No. 3257, 1990.

Stiglitz, Joseph and Andrew Weiss, "Credit Rationing in Markets with Imperfect Information," American Economic Review, June 1981, pp. 393-410.

Wilhelm, Mark O., "Bequest Behavior and the Effect of Heirs Earnings: Testing the Altruistic Model of Bequests," mimeo, The Pennsylvania State University, 1993. 
Table 3.1

Means and Standard Deviations of the Variables

INH

0.1783

(Inheritance in 1982 or $1983 \times 10^{-6}$ )

(0.2595)

$A G E$

40.4

(Donee's age in 1981)

(11.8)

$A G E^{2}$

1.770

(Age-squared $\times 10^{-3}$ )

(0.8706)

$A G E$ ?

0.02378

(= 1 if age unknown)

(0.1524)

MARRIED

0.8219

$(=1$ if married in 1981)

(0.3827)

KIDS

1.268

(= number of dependents in 1981)

(1.233)

$D C$

0.1876

(= 1 if decedent filed Schedule C)

(0.3905)

DC $x$ Child

0.1126

(= DC if donee the child of decedent)

$(0.3162)$

$A S S T$

0.3258

(Liquid assets in $1981 \times 10^{-6}$ )

$(0.8518)$

ASST $T^{2}$

0.8314

(Assets-squared $\times 10^{-13}$ )

HOME

0.7653

$(=1$ if homeowner in 1981)

(0.4239)

DBUS

(=1 if estate included a business)

0.3652

AGI

$(0.4816)$

0.06777

(Adjusted Gross Income in $1981 \times 10^{-6}$ )

(0.1386)

CASH8I

0.01593

(Schedule $C$ cash flow in $1981 \times 10^{-6}$ )

$(0.07525)$

CASH85

0.02249

(Schedule $C$ cash flow in $1985 \times 10^{-6}$ )

$(0.09381)$

RECPT8I

0.06455

(Schedule C receipts in $1981 \times 10^{6}$ )

$(0.2346)$

RECPT85

0.07913

(Schedule $\mathrm{C}$ receipts in $1985 \times 10^{-6}$ )

(0.2513)

$N$

1892

\footnotetext{
'Standard deviations are shown in parentheses. Statistics for CASH85 and RECPT85 are based on the 1,352 observations for surviving entrepreneurs.
} 
Table 3.2

Transition Rates

Low Inheritance

$(I N H<\$ 25,000)$

Medium Inheritance

$(\$ 25,000 \leq I N H \leq \$ 150,000)$

High Inheritance

( $I N H>\$ 150,000)$

All

\begin{tabular}{|c|c|c|c|c|}
\hline $\begin{array}{c}\text { Schedule } \\
\text { C }\end{array}$ & $\begin{array}{c}\text { Partnership/ } \\
\mathrm{S} \\
\text { corporation }\end{array}$ & $\begin{array}{c}\text { Wages } \\
\text { Only }\end{array}$ & Retirement & Total \\
\hline $\begin{array}{c}362 \\
0.674 \\
0.0202 \\
\end{array}$ & $\begin{array}{c}74 \\
0.138 \\
0.0149 \\
\end{array}$ & $\begin{array}{c}91 \\
0.170 \\
0.0162 \\
\end{array}$ & $\begin{array}{c}10 \\
0.0186 \\
0.0058 \\
\end{array}$ & 537 \\
\hline $\begin{array}{c}461 \\
0.6953 \\
0.0179 \\
\end{array}$ & $\begin{array}{c}108 \\
0.163 \\
0.0143 \\
\end{array}$ & $\begin{array}{c}79 \\
0.119 \\
0.0126 \\
\end{array}$ & $\begin{array}{c}15 \\
0.0226 \\
0.0058 \\
\end{array}$ & 663 \\
\hline $\begin{array}{c}529 \\
0.765 \\
0.0161 \\
\end{array}$ & $\begin{array}{r}95 \\
0.137 \\
0.0131 \\
\end{array}$ & $\begin{array}{c}46 \\
0.0665 \\
0.0095 \\
\end{array}$ & $\begin{array}{c}22 \\
0.0318 \\
0.0067 \\
\end{array}$ & 692 \\
\hline $\begin{array}{c}1352 \\
0.715 \\
0.0104 \\
\end{array}$ & $\begin{array}{c}277 \\
0.146 \\
0.0081 \\
\end{array}$ & $\begin{array}{c}216 \\
0.114 \\
0.0073 \\
\end{array}$ & $\begin{array}{c}47 \\
0.0248 \\
0.0036 \\
\end{array}$ & 1892 \\
\hline
\end{tabular}

- The first number in each cell is the number of individuals in that cell; the second number is the proportion of observations in the corresponding row that fall in that cell; and the third number is the standard deviation of the proportion. 
Table 4.1

Multinomial Logit Analysis of Entrepreneurs' Transition Probabilities*

(1)

Survive as

$\frac{\text { Variable }}{I N H}$

$A G E$

$A G E^{2}$

$A G E(?)$

MARRIED

KIDS

$D C$

$D C \times C H I L D$

$4 G I$

DBUS

ASST

$A S S T^{2}$

HOME

RECPT81

CONSTANT

Loglikelihood

$N$

$-0.04762$

$(0.07531)$

(0.2785)

0.4304

(0.1691)

\subsection{4 \\ (0.1808)}

(2)

Partnership/

S Corporation

1.558

(0.5881)

$-0.06551$

$(0.08189)$

0.5421

(1.011)

$-0.9994$

(1.769)

0.1136

$(0.2620)$

0.007679

(0.09148)

(3)

Retire

1.968

$(0.8056)$

$-0.06660$

(0.1495)

1.559

(1.795)

2.884

(3.024)

$-1.014$

(0.4108)

$-0.1100$

$(0.3460)$

0.3365

(0.4458)

$-0.4166$

$(0.2299)$

$-0.5152$

(0.6977)

(0.3729)

1.637

(1.925)

$-11.22$

(181.2)

$-.09119$

(3.036)

0.5104

0.3564

(0.2029)

(0.3812)

2.750

$(0.5820)$

2.849

(0.7112)

$-0.3061$

$-0.2898$

(0.06975)

$(0.09264)$

0.5253

$-0.6352$

(0.3903)

$(0.2347)$

$-1.656$

(4.213)

(1.625)

$-1.227$

(2.871)

$$
\begin{gathered}
-2.359 \\
(1.311)
\end{gathered}
$$

$$
\begin{array}{r}
0.5304 \\
(1.523)
\end{array}
$$$$
\text { (1.523) }
$$

$-1488.0$

1892

"Figures in parentheses are standard errors. The "omitted category" is the transition to being a wage earner. Thus, each column shows the determinants of the log of the ratio of the probability of making a transition to the state described at the top of the column to the probability of making a transition to wage eaming. Variables are defined in Table 3.1. 
Table A.1

Multinomial Logit Analysis of Entrepreneurs' Transition Probabilities

(Cash Flow Measure of Firm Performance)

(1)

Survive as

$\frac{\text { Variable }}{I N H}$

$A G E$

$A G E^{2}$

$A G E(?)$

MARRIED

KIDS

$D C$

$D G \times C H I L D$

$A G I$

$D B U S$

ASST

$A S S T^{2}$

HOME

CASH8I

CONSTANT

Loglikelihood

$N$
(2)

Partnership/

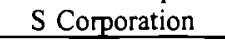

1.586

(0.5910)

$-0.05939$

$(0.08175)$

0.4720

(1.010)

$-0.8618$

(1.765)

0.1467

(0.2611)

0.004763

$(0.09104)$

$-0.1130$

(0.3465)

0.3726

(0.4476)

0.6793

(1.508)

0.5146

(0.2031)

2.907

(0.5902)

$-0.3043$

$(0.07055)$

0.5224

(0.2336)

5.667

(3.293)

0.4122

(1.520)

$-1495.7$

1892
(3)

\begin{tabular}{c} 
Retire \\
\hline 1.969 \\
$(0.7993)$ \\
-0.07501 \\
$(0.1482)$ \\
1.643 \\
$(1.779)$ \\
2.687 \\
$(3.000)$
\end{tabular}

$-1.072$

(0.4054)

$-0.3976$

$(0.2268)$

$-0.5126$

(0.6967)

$-11.24$

(184.2)

$-1.418$

(2.376)

0.3869

(0.3815)

3.028

(0.7169)

$-0.2892$

(0.09363)

$-0.6832$

(0.3894)

8.287

(4.365)

$-1.113$

(2.846)

See note to Table 4.1. 
Multinomial Logit Analysis of Entrepreneurs' Transition Probabilities (Expanded Definition of "Ëntrepreneur")

$\frac{\text { Variable }}{I N H}$

$A G E$

$A G E^{2}$

$A G E(?)$

MARRIED

KIDS

DC

$D C \times C H I L D$

$A G I$

DBUS

ASST

$A S S T^{2}$

HOME

CONSTANT

Loglikelihood

$N$

See note to Table 4.1.
(1)

Survive as

(2)

\begin{tabular}{c} 
Entrepreneur \\
\hline 1.641 \\
$(0.4093)$ \\
-0.01012 \\
$(0.04264)$ \\
0.1086 \\
$(0.5323)$
\end{tabular}

Retire

1.531

(0.5788)

$-0.1903$

(0.06404)

3.076

(0.8296)

$-0.4857$

(0.9008)

0.08741

(0.1711)

0.05353

(0.05712)

$-0.5653$

(1.235)

$-1.392$

(0.3034)

$-0.1705$

(0.1497)

$-0.1282$

(0.2256)

$-0.2255$

(0.4967)

0.1319

(0.2952)

3.240

(1.184)

$-1.732$

(1.135)

$-0.07840$

(1.784)

0.2748

(0.1300)

$-0.1955$

(0.2747)

1.6452

(0.3394)

2.085

$(0.4600)$

$-0.1688$

$(0.04055)$

$-0.2191$

(0.07362)

0.1368

(0.1536)

$-1.072$

(0.2974)

1.459

(0.7746)

(1.112)

$-1322.3$

3,520 